\title{
DESAIN PEMBELAJARAN MATERI FUNGSI LINIER MENGGUNAKAN PEMODELAN MATEMATIKA
}

\author{
Dyah Rahmawati $^{1)}$, Darmawijoyo ${ }^{2)}$, Hapizah $^{3)}$ \\ 1), 2), 3) Universitas Sriwijaya \\ E-mail: $\quad$ dyahrahmawati1912@gmail.com ${ }^{1)}$ \\ darmawijoyo@yahoo.com ${ }^{2}$ \\ $\underline{\text { hapizah_piza@yahoo.com }}^{3)}$
}

\begin{abstract}
This research is aimed to create a learning trajectory of linear functions concept using mathematical modeling. The applied learning approach is the Model Eliciting Activities (MEAs). Design research was chosen as the research method consisting of three main phases; preliminary design, teaching experiments, and retrospective analysis. This research was conducted in class $X$ in a public senior high school in Palembang. The result showed the design activity can encourage students to look at the form of modeling (charts/schemes/equation) that students make themself. Through steps on mathematical modeling takes students into the definition of the power to a linear functions, so the students had the idea in providing recommendations to solve real problems in life.
\end{abstract}

Keywords: design research, linier functions, mathematical modeling, model eliciting activities (MEAs)

\section{PENDAHULUAN}

Fungsi linier termasuk dalam aljabar. Belajar tentang fungsi linier merupakan konsep penting bagi siswa agar mampu mengidentifikasi dan menafsirkan hubungan antara dua variabel. Fungsi linier ditentukan berdasarkan pendekatan fungsional melalui masalah kontekstual yaitu jumlah biaya kerja. Jumlah biaya yang diperoleh sama dengan biaya per jam dikalikan dengan banyak jam kerja ditambah biaya tetap (Pierce, 2005). Sementara itu, Bardini dan Stacey (2004) menjelaskan bahwa belajar fungsi linier bertujuan agar siswa dapat mengidentifikasi struktur dua variabel yang terkait. Dalam hal ini, siswa memahami $x$ dapat bervariasi dalam nilai yang diwakilinya dan nilai $y$ atau $f(x)$ tergantung pada nilai $x$.

Kilpatrick dan Izsak (2008) dalam penelitiannya menjelaskan bahwa siswa masih banyak menghadapi tantangan dalam belajar aljabar, salah satunya menyelesaikan fungsi. Siswa masih banyak mengalami kesulitan memahami fungsi linier, sehingga memungkinkan terjadinya kesalahan sewaktu menjawab soal. Kesalahan yang sering dilakukan siswa dalam menyelesaikan fungsi linier adalah kurangnya pemahaman tentang variabel, koefisien, dan konstanta serta kesalahan dalam membaca soal baik soal biasa maupun soal cerita (Ngatini, 2012). Siswa juga mengalami kesulitan dalam mentransformasikan fungsi linier menjadi sebuah grafik, ini disebabkan oleh taraf berfikir siswa yang masih pada taraf konkrit (Sutomo, 2016). Kesulitan siswa juga dalam mengoperasikan operasi aritmatika yang melibatkan variabel fungsi dan tidak mampu dalam menarik kesimpulan.

Sistem pembelajaran yang ditemukan pada saat ini, khususnya pembelajaran matematika masih banyak yang didominasi oleh pembelajaran yang menggunakan metode ceramah dan tanya jawab (Syahrir, 2017). Hal inilah yang menyebabkan kesulitankesulitan siswa dalam mengembangkan kemampuannya. Sedangkan, untuk 
menjawab inovasi pembelajaran yang sesuai tuntutan abad 21 perlu adanya reformasi khususnya pendidikan matematika.

Upaya yang dilakukan guna mereformasi pendidikan matematika mengharuskan guru membangun budaya kelas, dimana diskusi kelas yang melibatkan dugaan, perumusan, dan pembenaran, memainkan peran penting dalam pembelajaran (Gravemeijer, 2004). Dan tentunya diperlukan suatu cara bagaimana mengarahkan proses itu, bagaimana bisa membuat siswa menemukan kembali apa yang guru inginkan untuk mereka temukan kembali. Dengan demikian, guru sangat berperan dalam merancang pembelajaran sehingga siswa dapat lebih mudah untuk memahami konsepkonsep fungsi linier menggunakan pendekatan pembelajaran matematika yang sesuai.

Purwanto (2002) menjelaskan bahwa terdapat banyak cara untuk menciptakan agar pembelajaran matematika nyaman dan menyenangkan, antara lain dengan cara memperlihatkan sikap ramah dalam menanggapi berbagai kesalahan siswa, mengusahakan agar siswa dikondisikan untuk bersikap terbuka, mengajak siswa untuk belajar sambil bermain, dan menggunakan metode serta pendekatan yang bervariasi. Matematika bukan hanya materi yang ditransfer oleh guru ke siswa, tetapi siswa seharusnya diberi kesempatan dan dibimbing ke dalam situasi untuk menemukan kembali (reinvent) konsep matematika dengan cara mereka sendiri (Gravemeijer, 2004). Salah satu upaya yang dilakukan untuk mengembangkan kemampuan matematika yaitu menyediakan perangkat pembelajaran yang mendukung pengembangan kemampuan literasi matematika siswa. Representasinya berupa permasalahan- permasalahan yang sering ditemui siswa. Representasi merupakan elemen penting dalam mendukung pemahaman siswa terhadap konsep matematika, hubungan- hubungannya, mengkomunikasikan pendekatanpendekatan matematika dan dalam memberikan argumen (NCTM, 2000). Tujuannya agar siswa terbiasa dalam memecahkan masalah dengan membuat solusi matematika untuk kehidupan nantinya.

Untuk menjembatani berbagai manfaat matematika dalam mempermudah dan menjadi tool dalam berbagai lini diperlukan sebuah "mesin" yang mampu mengolah berbagai persoalan konkrit menjadi sebuah model atau pola dan nantinya akan menghasilkan suatu solusi praktis. Dalam matematika dikenal sebuah model. Model merupakan sebuah simplifikasi atau penyederhanaan berbagai fenomena nyata dalam bentuk matematika. Model matematika yang dihasilkan, dapat berupa persamaan, pertidaksamaan, sistem persamaan atau lainnya terdiri atas sekumpulan simbol yang disebut variabel atau besaran yang kemudian di dalamnya digunakan operasi matematika. Metode tersebut disebut dengan pemodelan matematika (mathematical modeling).

Menurut Ang (2009) pemodelan matematika adalah proses pemahaman, menyederhanakan dan memecahkan masalah kehidupan nyata dalam hal matematika. Pemodelan matematika adalah bahasa matematika yang digunakan untuk mengkuantifikasi suatu fenomena atau kejadian nyata hampir di segala bidang di suatu kondisi tertentu (Nuraini, 2011). Menurut Bliss dan Libertini (2016) dalam buku Gaimme chapter 1 mengatakan bahwa "Mathematical modeling is a process that uses mathematics to represent, analyze, make predictions or otherwise 
provide insight into real world phenomena". Jadi dapat disimpulkan bahwa pemodelan matematika merupakan proses menggunakan matematika sebagai representasi dalam memahami masalah, menyederhanakan masalah, dan menyelesaikan masalah dalam kehidupan nyata.

Dalam proses pemodelan sangat penting karena siswa dituntut mampu mengkomunikasikan gagasan matematika dalam bentuk model atau rumusan matematika. Dalam proses penyelesaiannya, pemodelan matematika memiliki komponenkomponen sebagai berikut: (Bliss \& Libertini, 2016)

matematika, aspek komunikasi menjadi

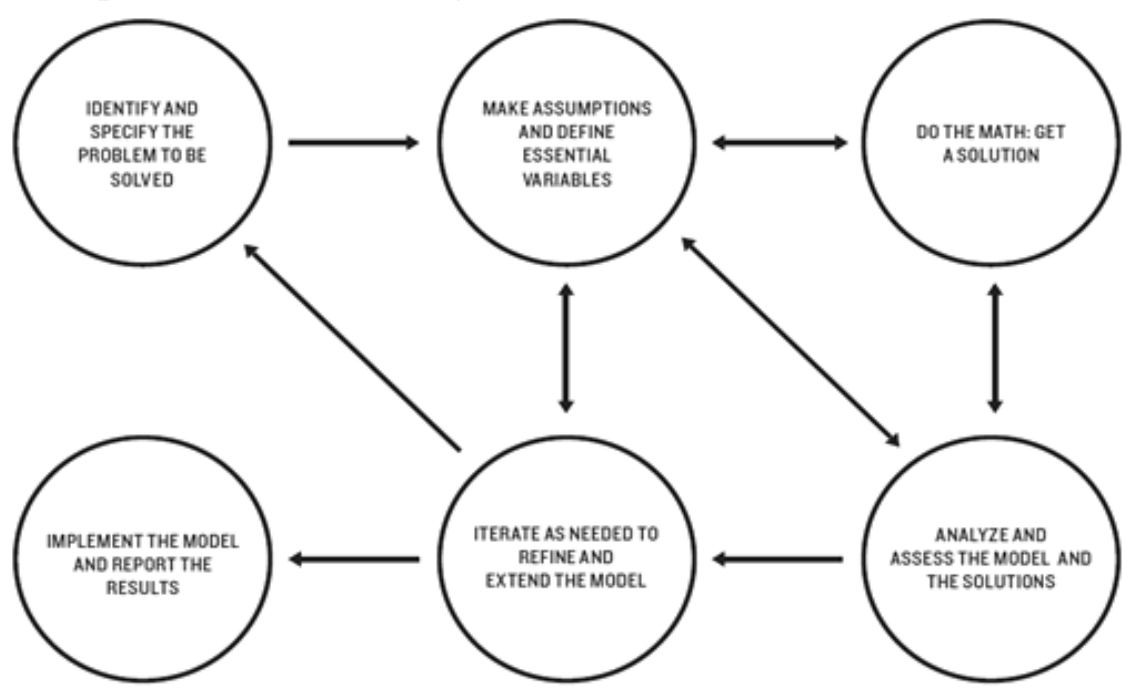

Gambar 1. Skema Proses Pemodelan Matematika GAIMME

1. Mengidentifikasi Masalah:

Mengidentifikasi sesuatu di dunia nyata yang kita ingin tahu, lakukan, atau memahami. Hasilnya adalah pertanyaan di dunia nyata.

2. Membuat asumsi dan identifikasi variabel: Memilih 'benda' yang tampaknya penting dalam pertanyaan dunia nyata dan mengidentifikasi hubungan diantara mereka. Kemudian memutuskan apa yang akan diteruskan dan apa yang akan diabaikan tentang objek dan keterkaitan mereka. Hasilnya adalah versi ideal dari pertanyaan awal.

3. Mematematikakan

Menerjemahkan versi ideal dalam istilah matematika dan memperoleh matematika perumusan pertanyaan ideal. formulasi ini adalah model. Kemudian melakukan matematika untuk melihat apa wawasan dan hasil yang didapatkan.

4. Analisis dan menilai solusi :

Menganggap apakah itu mengatasi masalah? Apakah masuk akal bila diterjemahkan kembali ke dalam dunia nyata? Apakah hasil praktis, jawaban yang masuk akal, konsekuensi diterima?

5. Menginterpretasi:

Proses menginterpretasi diperlukan untuk memperbaiki dan memperluas model.

6. Melaksanakan pemodelan : Untuk dunia nyata, aplikasi praktis, lalu melaporkan hasilnya kepada orang lain dan melaksanakannya. 
Jadi, dengan menggunakan pemodelan matematika, (1) siswa diharapkan mampu dalam mengidentifikasi kejadian-kejadian yang terjadi di sekitar, (2) siswa dapat mengeksplorasi pengetahuan lebih tentang masalah dunia nyata dengan mengaitkan masalah matematika, dan (3) siswa mampu menemukan cara yang tepat dalam memecahkan masalah matematika berdasarkan fenomena dunia nyata. Ini sejalan dengan Permendikbud No.22 Tahun 2016 mengenai Standar Isi mata pelajaran matematika yang sifatnya problem based learning, yaitu pembelajaran berbasis pada masalah-masalah yang ada.

Kho (dalam Yee \& Hoe, 2009) menyatakan ada empat alasan mengapa pemodelan matematika diajarkan kepada siswa, yaitu: (1) membantu siswa mendapatkan wawasan yang lebih baik mengenai konsep-konsep matematika; (2) membantu siswa merencanakan langkah-langkah solusi untuk memecahkan masalah matematika; (3) dapat dibandingkan tetapi sedikit abstrak atau semi konkret daripada metode aljabar; dan (4) merangsang siswa untuk memecahkan masalah yang lebih menantang.

Pemodelan matematika berbeda dengan model matematika, dalam penggunaannya perumusan pemodelan merujuk pada tujuan yang diinginkan dari konstruksi model (Nuraini, 2011). Pollak (2003) berpendapat bahwa semua siswa harus belajar pemodelan matematika untuk menggunakan matematika dalam kehidupan seharihari mereka, sebagai warga negara, dan dalam angkatan kerja. Blum dan Ferri (2009) juga menambahkan bahwa pemodelan matematika dapat mendukung pembelajaran matematika dalam hal motivasi, pemahaman, ingatan, dan dalam hal menunjukkan apa matematika dan bagaimana bisa digunakan. Oleh sebab itu, pemodelan matematika sudah selayaknya diterapkan dalam proses pembelajaran di sekolah.

Model Eliciting Activities (MEAs) adalah sebuah pendekatan pembelajaran untuk memahami, menjelaskan dan mengkomunikasikan konsep-konsep yang terkandung dalam suatu sajian melalui proses pemodelan matematika (Permana, 2007). Sejalan dengan itu, Widyastuti (2011) menjelaskan bahwa pembelajaran MEAs didasarkan pada situasi kehidupan nyata siswa, bekerja dalam kelompok kecil, dan menyajikan sebuah model matematis sebagai solusi. Selanjutnya, Permana (2007) menjelaskan bahwa MEAs memberi peluang yang sangat besar kepada siswa untuk mengeksplorasi pengetahuannya dalam belajar matematika, diharapkan dapat membuat siswa mengubah pendangannya bahwa matematika sebagai pelajaran yang tidak sulit dan siswa sebenarnya mampu mempelajari matematika. Proses belajar siswa dengan menggunakan MEAs menjadi bermakna karena siswa dapat menghubungkan konsep yang dipelajari dengan konsep yang sudah dikenalnya serta menekankan siswa untuk belajar secara aktif. Berdasarkan pendapat di atas dapat dikatakan bahwa untuk menerapkan pemodelan matematika, pendekatan pembelajaran yang sesuai dengan tahapan dalam pemodelan matematika adalah dengan pendekatan Model Eliciting Activities (MEAs).

Tujuan dari penelitian ini adalah untuk mengetahui peran pemodelan matematika dalam mendukung kemampuan siswa memahami konsep fungsi linier melalui strategi yang digunakan dan menghasilkan lintasan belajar materi fungsi linier yang dikembangkan berdasarkan pemodelan matematika. 


\section{METODE PENELITIAN}

Penelitian ini menggunakan metode penelitian desain (design research), yaitu suatu kajian sistematis tentang merancang, mengembangkan dan mengevaluasi intervensi pendidikan (seperti program, strategi dan bahan pembelajaran, produk dan sistem) sebagai solusi untuk memecahkan masalah yang kompleks dalam praktik pendidikan, yang juga bertujuan untuk memajukan pengetahuan kita tentang karakteristik dari intervensi-intervensi tersebut serta proses perancangan dan pengembangannya (Plomp \& Nieveen, 2007). Ini merupakan suatu cara yang tepat untuk menjawab pertanyaan peneliti dan mencapai tujuan dari penelitian.

Pada penelitian ini, terdapat suatu alur pembelajaran pada materi fungsi linier menggunakan pemodelan matematika berupa sederetan aktivitas siswa yakni dugaan-dugaan strategi dan pemikiran siswa yang dapat berubah dan berkembang selama proses pembelajaran. Hal ini menunjukkan bahwa terjadi siklus pada proses yang berulang dari eksperimen pemikiran (thought experiment) menuju eksperimen pembelajaran (intruction experiment). Dalam setiap siklus, dilakukan antisipasi eksperimen pemikiran dengan membayangkan bagaimana aktivitas pembelajaran yang diusulkan dapat digunakan di dalam kelas, dan apa yang dapat siswa pelajari karena mereka berpartisipasi di dalamnya (Bustang, Zulkardi, Darmawijoyo, Dolk, dan van Eerde, 2013).

Gravemeijer dan Cobb (2006) menyatakan bahwa ada 3 tahap dalam pelaksanaan design research yaitu desain awal, percobaan mengajar dan analisis retrospektif.

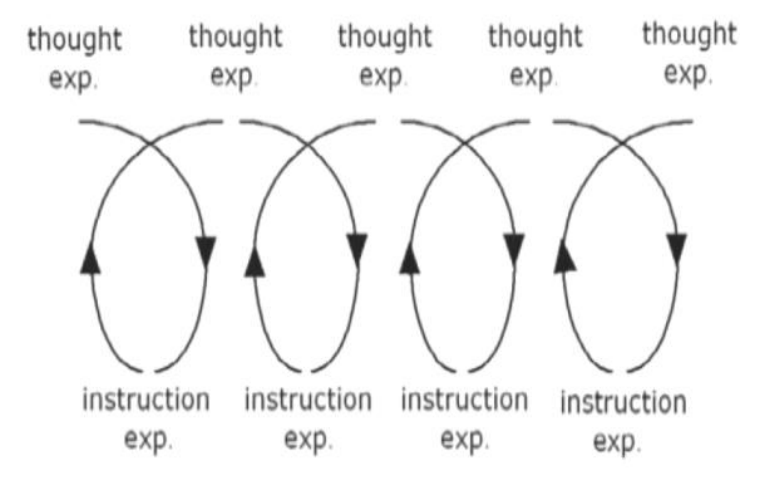

Gambar 2. Siklik Design Research

(Gravemeijer \& Cobb, 2006)

Pada tahap desain awal dilakukan kajianliteratur yaitu mengenai materi fungsi linier, pemodelan matematika, dan pendekatan Model Eliciting Activities (MEAs). Setelah itu, dibentuk suatu dugaan strategi dan pemikiran siswa padaproses pembelajaran. Selanjutkan akan didesain hypothetical learning trajectory(HLT).

Pada tahap percobaan pengajaran, melibatkan dua siklus, yaitu pilot experiment (siklus 1) dan teaching experiment (siklus 2). Pilot experiment bertujuan untuk menguji HLT yang telah dirancang, kemudian direvisi dilaksanakan pada teaching experiment. Data dikumpulkan melalui pengambilan video, Lembar Kerja Peserta Didik (LKPD), pre-test, posttest, wawancara, dan catatan lapangan. Selanjutnya dilakukan analisis retrospektif dengan menganalisa hasil kegiatan dan HLT yang telah dibuat. Tujuan dari analisis retrospektif secara umum adalah untuk mengembangkan local instructional theory (LIT). Pada tahap ini, HLT dibandingkan dengan pembelajaran siswa yang sebenarnya, hasilnya digunakan untuk menjawab rumusan masalah. Dalam desain pembelajaran ini, peneliti mengembangkan lima aktivitas dalam memahami konsep fungsi linier. Kegiatan ini secara garis besar untuk 
mengetahui strategi siswa dalam menemukan penyelesaian dari permasalahan yang diberikan dengan menggunakan langkah-langkah pemodelan matematika.

\section{HASIL PENELITIAN DAN PEMBAHASAN}

Penelitian ini menghasilkan lintasan belajar untuk materi fungsi linier dengan pemodelan matematika menggunakan konteks kegiatan ekonomi produksi, distribusi dan konsumsi. Pada tahap teaching experiment melibatkan seorang guru model dan 38 orang siswa. Sedangkan peneliti bertindak sebagai observer untuk mengamati perkembangan yang terjadi saat pembelajaran. Penelitian ini didesain dalam dua lembar kerja peserta didik (LKPD) yang terdiri dari lima

Berkurangnya daya dari aliran listrik, membuat produksi air bersih PDAM Tirta Musis Palembang menurun. Hal ini berdampak pada berkurangnya juga aliran air kepada pelanggan dan mengharuskan seluruh pelanggan PDAM menghemat pemakaian air bersih.

Direktur Operasional PDAM Tirta Musi Palembang, Andi Wijaya mengatakan, PDAM terpaksa mengurangi produksi air bersih selama beberapa hari ke depan. Padahal menurut date DDAM hingga akhir 2017 jumlah pelanggan sudah mencapai 270.000. Ia mengatakan, pihaknyo harus menurunkan kapasitas produksi air bersih karena tegangan yang masuk lebih rendah dar kebutuhan alat-alat termasuk pompa air. PD AM pun menurunkan produksi hingga 50 persen, dar: produksi normal 3800 liter perdetik.

"PLN kemungkinan sedang ada trouble, maka mohon pelanggan memaklumi pasokan air menjadi berkurang," ungkapnya. (Sumber : beritapagico.id)

Berapa liter produksi air bersih yang bisa dihasilkan PDAM Tirta Musi saat ada trouble daya aliran listrik? Apakah mampu mencukupi kebutuhan pelanggan? Berapa lama waktu minimal trouble agar pelanggan tidak kekurangan air bersih ? Berikan alasanmu ! aktivitas. Berikut ini deskripsi dari aktivitas-aktivitas tersebut.

\section{Aktivitas 1: Menentukan dan mengidentifikasi hubungan antara daerah asal, daerah hasil suatu fungsi dan ekspresi simbolik.}

Untuk mengawali serangkaian aktivitas yang dilakukan, guru membuka pelajaran, memeriksa kesiapan kelas siswa terlebih dahulu, menyampaikan tujuan pembelajaran, kemudian guru memberikan apersepsi dengan mengingatkan kembali tentang pengertian fungsi dan menyampaikan tentang bagaimana pembelajaran akan dilakukan.

Selanjutnya, guru meminta siswa untuk berkelompok yang terdiri dari 3 atau 4 orang. Lalu, guru membagikan lembar aktivitas 1. Dengan panduan guru, siswa berdiskusi menyelesaikan masalah melalui langkah-langkah pemodelan matematika.

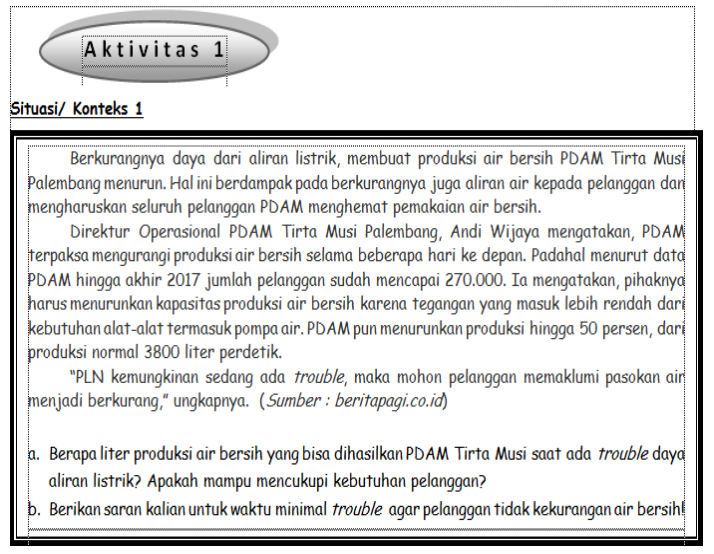

Gambar 3. Konteks Produksi Air Bersih PDAM

Pada aktivitas 1 revisi dilakukan dari segi redaksi pertanyaan. Karena setelah diujicobakan pada siklus 1 tidak muncul pernyataan siswa mengenai saran atau rekomendasi yang dibutuhkan untuk menjawab permasalahan yang diberikan, sehingga belum terlihat kemampuan siswa untuk mengatasi masalah dari hasil identifikasi daerah asal dan daerah hasil suatu fungsi linier.
Berikut ini adalah foto-foto kegiatan pembelajaran pada siklus 2 .

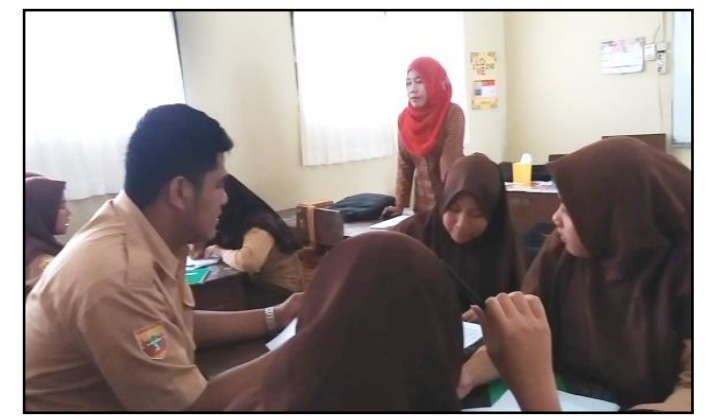




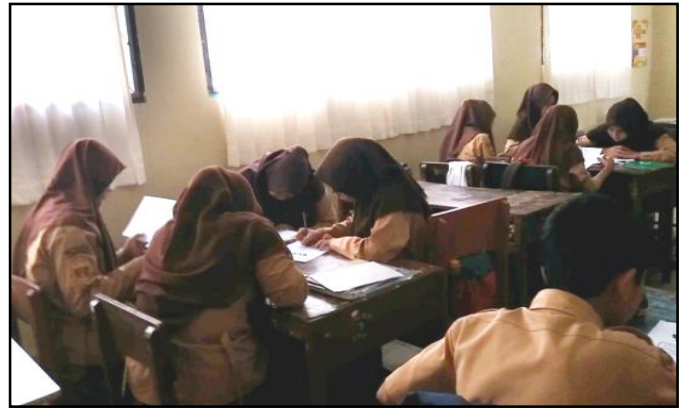

Gambar 4. Teaching Experiment

Dilihat dari jawaban siswa, telah menunjukkan bahwa siswa mampu melakukan identifikasi masalah, membuat asumsi, melakukan proses matematika untuk mendapatkan solusi dan memberikan rekomendasi, meskipun jawaban mereka tidak bisa disamaratakan. Berdasarkan video wawancara kepada beberapa siswa diperoleh alur pemahaman siswa untuk menentukan dan mengidentifikasi hubungan antara daerah asal dan daerah hasil suatu fungsi linier, serta ekspresi simboliknya. Berikut transkrip percakapannya.

Guru :"Dari masalah itu himpunan apa saja yang bisa kalian buat nak?"

Siswa :"Ada himpunan waktu dan himpunan banyak air bersih yang diproduksi bu."

Guru :"Baik. Bagaimana kalian menentukan simbol untuk himpunan tersebut?"

Siswa :"Jadi waktu disimbolkan dengan $x$, banyak air dalam 1 jam itu a dan hasilnya $\operatorname{adalah} f(x)$."

Guru : "Yang mana daerah asal dan daerah hasilnya?"

Siswa : "Daerah asal itu $x$ dan daerah hasil itu $f(x)$."

Guru : "Daerah asal apa?"

Siswa : "Daerah asalnya itu himpunan waktu."

Guru : "Daerah hasil?"

\section{Siswa :"Daerah hasil adalah banyaknya produksi air bersih." \\ Guru : "Oke"}

Jawaban siswa berdasarkan pemodelan matematika adalah sebagai berikut.

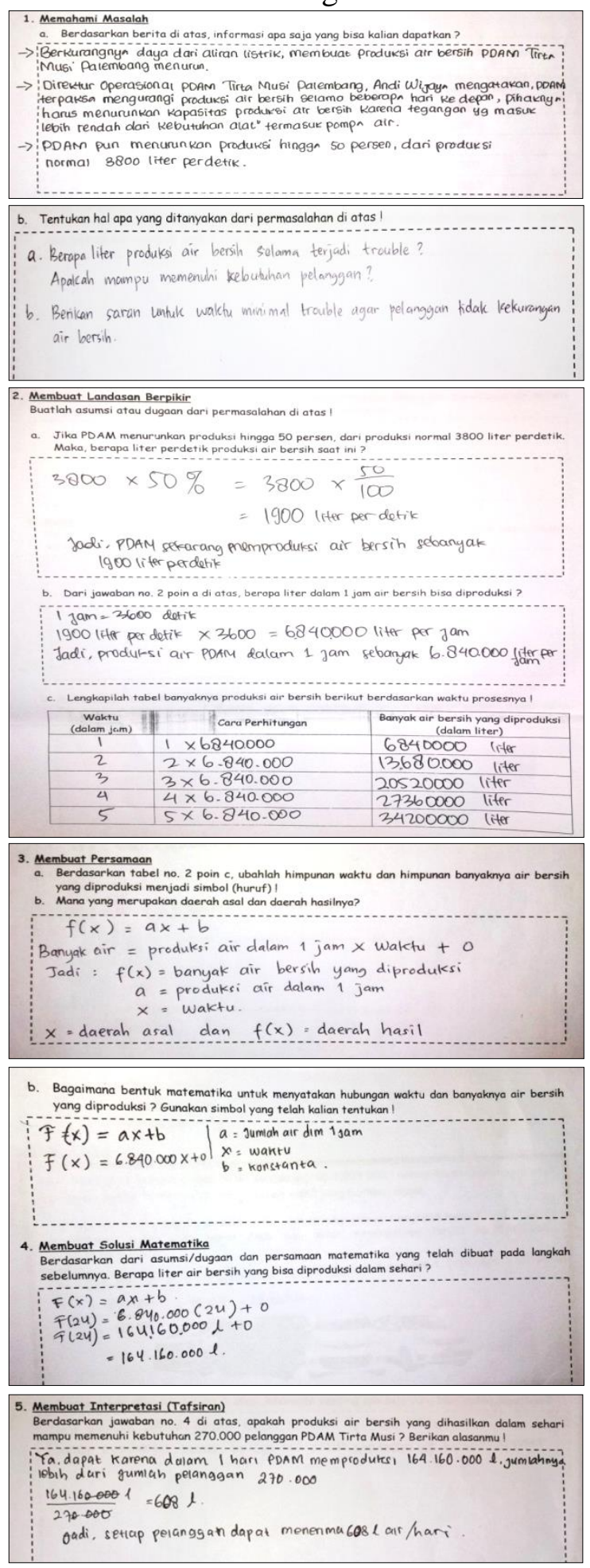




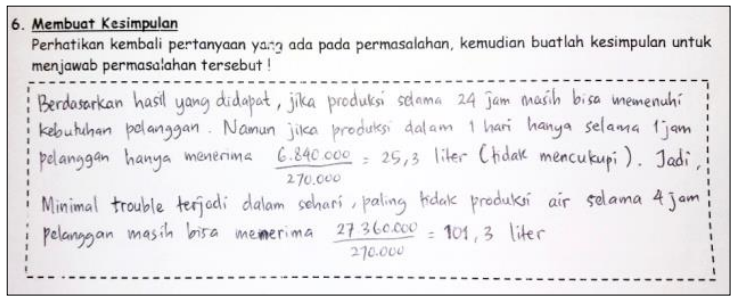

Gambar 5. Jawaban Siswa Aktivitas 1

Aktivitas 2: Menyajikan masalah yang melibatkan daerah asal dan daerah hasil fungsi linier, serta ekspresi simbolik.

Pada aktivitas 2, guru membagikan permasalahan tentang penjualan mobil, dimana siswa dilibatkan jika harus menjadi seorang pegawai dealer dengan menargetkan penghasilan maksimal dalam sebulan. Selama pembelajaran guru berperan sebagai fasilitator dan memberi waktu kepada siswa untuk berdiskusi dan menyampaikan pendapat dan saran untuk menyelesaikan permasalahan. Langkah-langkah yang dilakukan siswa menggunakan pemodelan matematika yaitu memahami masalah, membuat landasan berpikir, membuat persamaan, menyelesaikan persamaan, mengecek atau menginterpretasi, membuat kesimpulan dan melaporkan hasil.

Berikut ini adalah permasalahan yang diberikan pada aktivitas 2 .

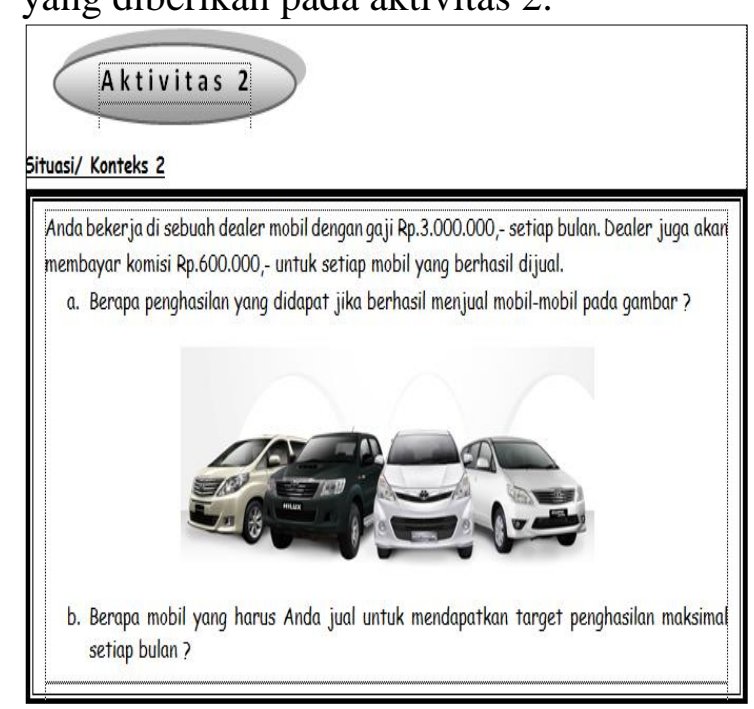

Gambar 6. Konteks Penjualan Mobil
Berdasarkan permasalahan tersebut siswa mampu menyajikan masalah yang melibatkan daerah asal dan daerah hasil fungsi linier, serta membuat ekspresi simbolik fungsi linier untuk digunakan sebagai perhitungan lainnya jika mobil yang dijual lebih banyak atau lebih sedikit, sesuai target penjualan yang diinginkan.

Jawaban siswa untuk aktivitas 2 dapat dilihat pada gambar 7 .

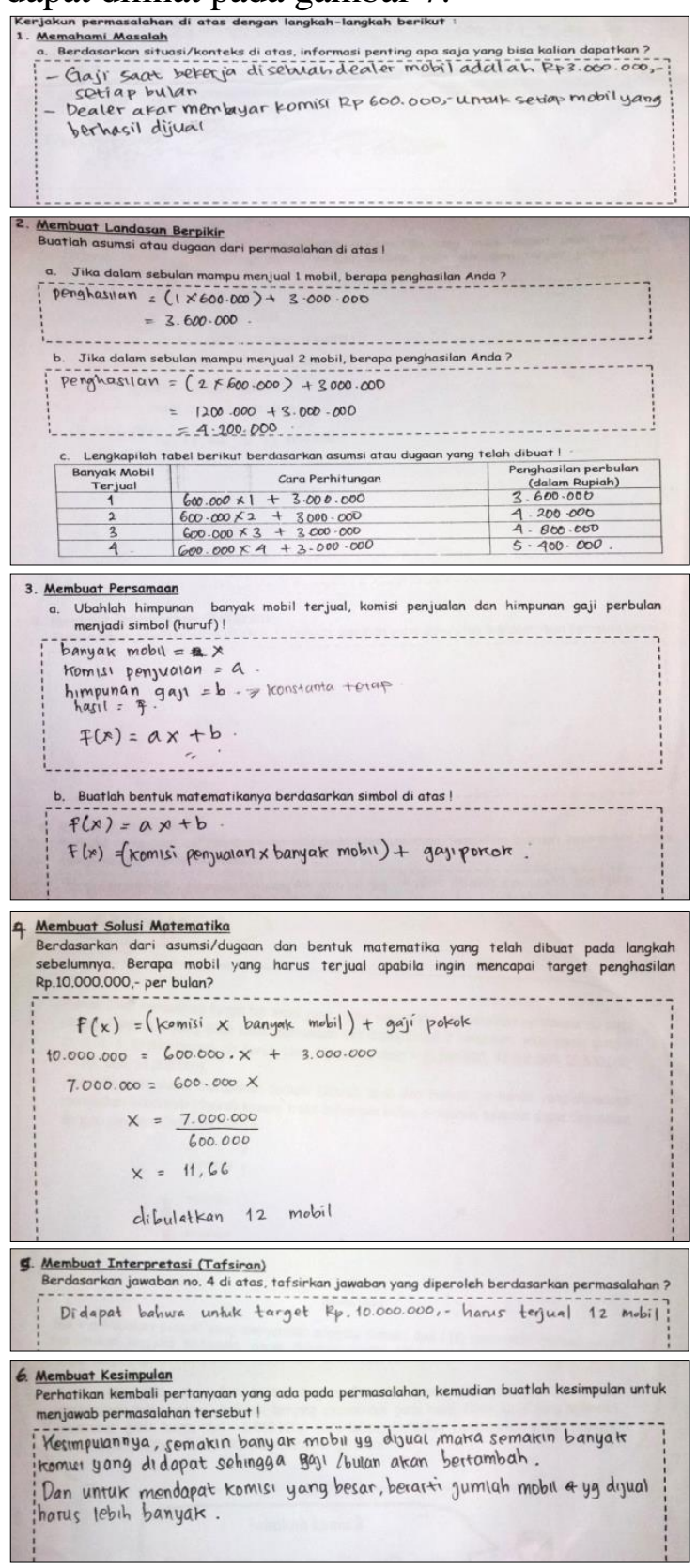

Gambar 7. Jawaban Siswa Aktivitas 2 


\section{Aktivitas 3: Menyajikan masalah yang melibatkan fungsi linier menggunakan grafik pada bidang cartesius.}

Pada aktivitas 3 ini siswa diminta menggambarkan grafik fungsi linier untuk permasalahan pada aktivitas 2 sebelumnya. Sehingga dari grafik yang dihasilkan akan terlihat grafik peningkatan penghasilan perbulan apabila penjualan mobil juga meningkat.

Berikut ini adalah jawaban siswa untuk aktivitas 3 .

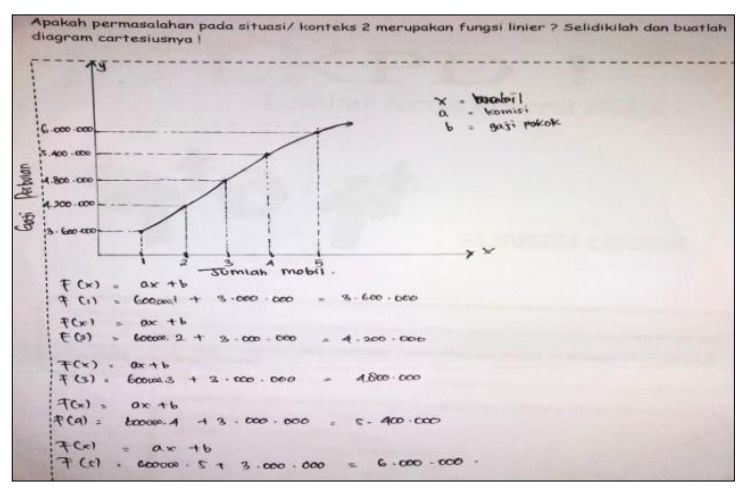

Gambar 8. Jawaban Siswa Aktivitas 3

Dari grafik yang dibuat, siswa juga menjadi lebih paham mengenai konsep bahwa setiap fungsi linier memiliki grafik pada bidang Cartesius yang berbentuk garis lurus. Pemahaman siswa ini terlihat dari video percakapan saat pembelajaran. Berikut transkrip percakapannya.

Guru : Bagaimana untuk

Siswa : "Ini kita buat dulu grafiknya. Kita buat garis $y$ dan garis $x$. $x$ itu jumlah mobil terjual dan $y$ ini total gaji keseluruhan."

Guru : "Iya.. Lalu?"

Siswa :"Jadi kita buat kalau mobilnya 1. Seperti ini rumusnya, $f(x)=a x+b$. $x$ sama dengan mobil, kalau b itu gaji dan a itu komisi."

Guru : "Oke, jadi bagaimana?"

Siswa :"Jadi komisi permobil itu 600.000 dikali $x$ itu kan 1 mobilnya jadi 1, ditambah $b$ gaji, gajinya itu 3.000.000. Maka 600.000 dikali 1 ditambah 3.000 .000 sama dengan 3.600.000. Jadi kalau 1 mobil penghasilannya 3.600.000."

Guru :"Bagaimana untuk mobil lebih dari 1?”

Siswa :"sama perhitungannya bu, gunakan $f(x)=a x+b, x$ nya itu mobilnya 2. Jadi diganti 2. Dan seterusnya."

Guru :"Lalu grafiknya bagaimana?'

Siswa :"Jadi dihubungkan, 1 dengan total gaji mobil 1, mobil 2, mobil 3, mobil 4 dan mobil 5 seterusnya. Lalu buat grafik dengan menghubungkan titiktitiknya."

Guru : "Bentuknya apa grafiknya?"

Siswa : "Grafik naik"

Guru :"Pertanyaan di atas itu apa?"

Siswa : "Apakah permasalahan pada situasi / konteks 2 merupakan fungsi linier? Iyaa termasuk fungsi linier."

Guru : "Mengapa?"

Siswa : "Karena ini, setiap fungsi linier memiliki grafik pada bidang cartesius yang berbentuk garis lurus."

Guru : "Okee.." 
ISSN 2089-8703 (Print) Vol. 7, No. 1 (2018)

ISSN 2442-5419 (Online)

\section{Aktivitas 4: Menyelesaikan masalah kontekstual yang dinyatakan dengan fungsi linier.}

Aktivitas 4 bertujuan agar siswa mampu menyelesaikan masalah real yang dinyatakan dengan fungsi linier. Berikut permasalahan pada aktivitas 4 .

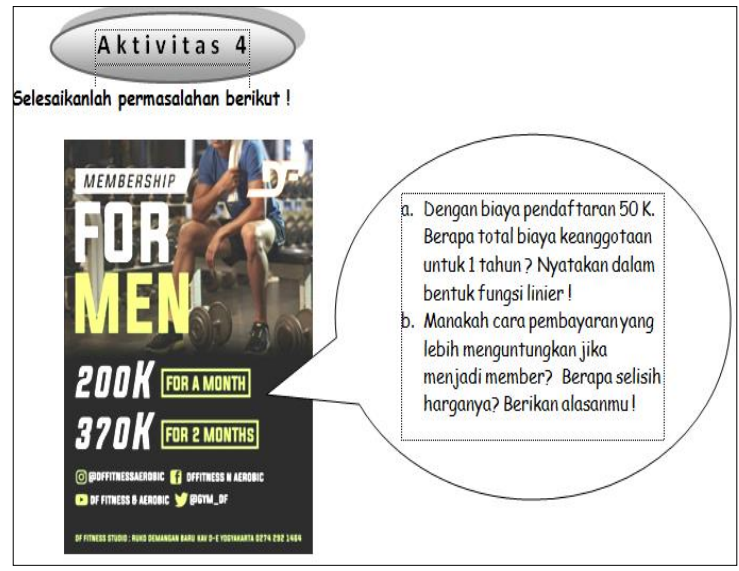

Gambar 9. Konteks Membership Gym

Berdasarkan jawaban siswa, terlihat siswa sudah mampu menyatakan fungsi linier untuk menyelesaikan masalah yang diberikan. Berikut jawaban siswa untuk aktivitas 4 yang diberikan.

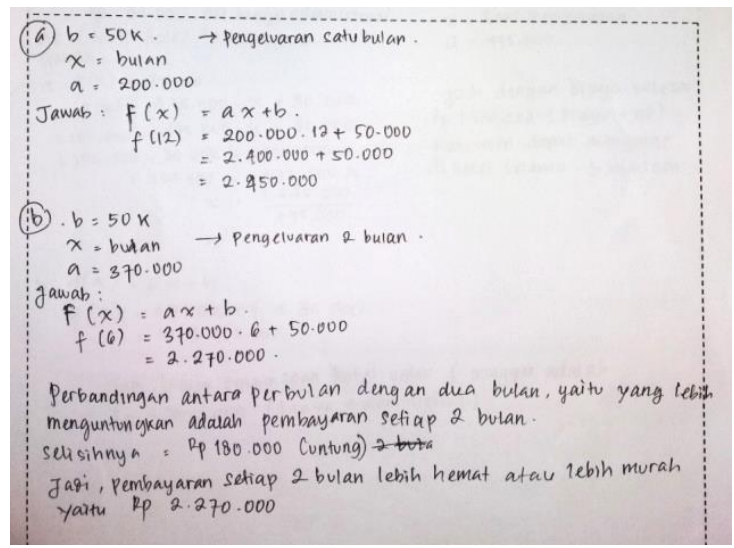

Gambar 10. Jawaban Siswa Aktivitas 4

\section{Aktivitas 5: Menyelesaikan masalah kontekstual yang dinyatakan dengan fungsi linier.}

Aktivitas 5 juga bertujuan agar siswa mampu menyelesaikan masalah real yang dinyatakan dengan fungsi linier. Namun masalah yang diberikan lebih kompleks dan membutuhkan analisis siswa yang lebih mendalam. Siswa diminta menentukan pemesanan tiket pesawat yang lebih murah dan efisien waktu berdasarkan jadwal penerbangan dan harga yang tersedia pada Traveloka. Berikut permasalahan pada aktivitas 5.

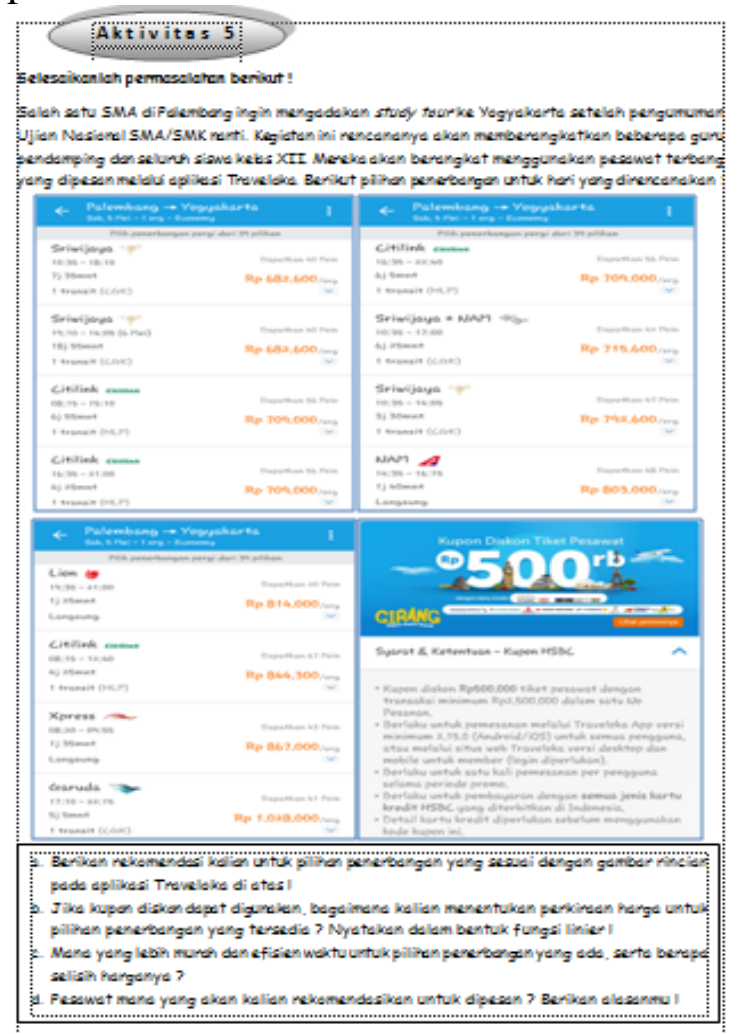

Gambar 11. Konteks Tiket Pesawat

Berdasarkan jawaban siswa, terlihat siswa sudah mampu menyatakan fungsi linier untuk menyelesaikan masalah yang diberikan. Berikut jawaban siswa untuk aktivitas 5 yang diberikan.

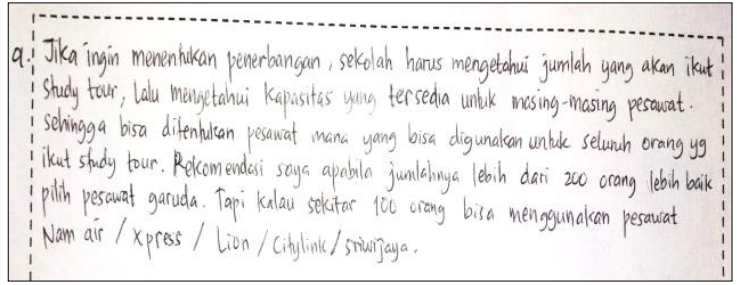



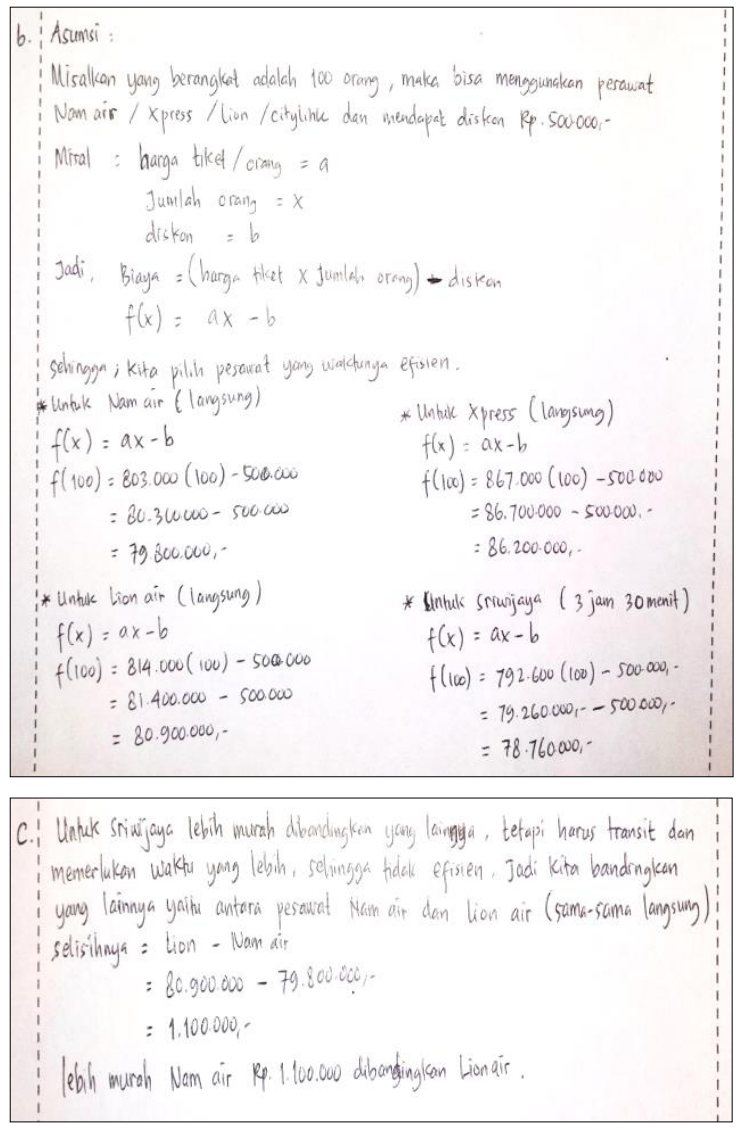

d. Pesarat yang bisa direkemendasican adalah pesewsat Nam air. karena

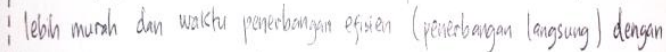
biays R2. 79.800000 - whate 100 orang

Gambar 12. Jawaban Siswa Aktivitas 5

Berdasarkan hasil penelitian, didapat lintasan belajar yang dilakukan mulai dari berkembangnya kemampuan siswa dari memahami masalah, membuat landasan berpikir, membuat persamaan, membuat solusi matematika, menginterpretasikan, menyimpulkan serta mengekspos hasil yang didapat untuk menyelesaikan permasalahan. Aktivitas menggunakan langkah-langkah dalam pemodelan matematika yang dilakukan oleh siswa merupakan jembatan dari pengetahuan informal ke pengetahuan formal, kemudian kembali lagi ke informal. Aktivitas pertama yaitu mengidentifikasi daerah asal dan daerah hasil suatu fungsi melalui konteks produksi air bersih PDAM. Berdasarkan hasil pekerjaan siswa didapat bahwa mereka dapat menyelesaikan permasalahan tersebut dengan tepat melalui langkah pemodelan yang didesain.

Aktivitas kedua didesain untuk menuntun siswa kepada aktivitas ketiga, yaitu menyajikan masalah yang melibatkan daerah asal dan daerah hasil fungsi linier, ekspresi simbolik serta sketsa grafik fungsi linier. Sebagian besar siswa menjawab dengan tepat.

Aktivitas ketiga, siswa menyajikan data ke dalam bentuk grafik fungsi linier dan menampilkan kembali strategi seperti pada aktivitas dua. Siswa membuat rumusan dengan memasukkan nilai $\mathrm{x}$ sebagai daerah asal untuk mendapatkan daerah hasilnya berdasarkan rumus fungsi linier yang mereka buat. Kemudian siswa menarik kesimpulan dari aktivitas-aktivitas yang telah dilakukan.

Terakhir, pada pertemuan kedua adalah aktivitas keempat dan kelima, siswa menyelesaikan masalah kontekstual yang dinyatakan dengan fungsi linier.

Pada setiap aktivitas yang dilakukan, penutup pembelajaran adalah dengan mempresentasikan hasil diskusi atau aktivitas yang mereka lakukan. Kegiatan presentasi memberikan kesempatan kepada siswa untuk mengungkapkan pendapat dan saling menghargai.

Penelitian ini menggunakan pendekatan Model Eliciting Activities (MEAs) dalam proses pembelajaran. Enam prinsip MEAs telah dilaksanakan dalam proses pembelajaran, yaitu (1) prinsip konstruksi model (the model construction principle); (2) prinsip realitas (the reality principle); (3) prinsip penilaian diri(the selfassessment principle); (4) prinsip pembuatan dokumentasi (the construct 
documentation principle); (5) prinsip kemampuan mentransfer dan memodifikasi (the construct shareability and reusability principle); dan (6) prinsip prototipe efektif (the effective prototype Principle).

Selama pelaksanaan MEAs, siswa membuat kesan tentang situasi-situasi bermakna, menemukan, dan memperluas konstruksi matematis mereka sendiri. Hal ini sesuai dengan yang dinyatakan oleh Carlson dkk (dalam Chamberlin dan Moon, 2008). Salah satu tujuan dari pembelajaran MEAs adalah memberikan kesempatan kepada siswa untuk mengontrol pembelajaran mereka sendiri dengan pengarahan proses. Menciptakan model matematis merupakan salah satu cara mencapai self-directed learning. MEAs memiliki potensi untuk membantu siswa belajar lebih mendalam, mempertahankan apa yang mereka pelajari, dan mentransfer belajar mereka dengan konteks masalah lainnya.

\section{KESIMPULAN DAN SARAN}

Berdasarkan hasil dan pembahasan yang telah diuraikan, dapat disimpulkan bahwa learning trajectory yang diimplementasikan dalam penelitian dengan menggunakan pemodelan matematika telah membantu siswa dalam memahami konsep fungsi linier. Dalam proses pembelajaran yang telah dilakukan pemahaman siswa terhadap materi fungsi linier berkembang dari tahap informal menuju formal, dan melalui tahapan formal tersebut mampu menjawab permasalahan yang terjadi dalam dunia nyata. Adapun tahapan pemahaman yang dimiliki siswa antara lain.

1. Siswa memahami konsep fungsi linier melalui situasi yang sering terjadi dalam kehidupan. Situasi awal yang diberikan adalah ketika terjadi pengurangan aliran listrik dari PLN pada perusahaan PDAM sehingga terjadi pengurangan pasokan air bersih karena produksinya terganggu. Melalui tahapan ini siswa mengetahui mana yang merupakan daerah asal maupun daerah hasil suatu fungsi. Selain itu siswa mampu mendefinisikan fungsi linier menggunakan bahasa mereka sendiri. Dilihat dari waktu produksi air bersih merupakan daerah asal suatu fungsi. Sedangkan jumlah produksi air bersih merupakan daerah hasilnya. Hal ini merupakan representasi bagi siswabahwa suatu fungsi linier mempunyai daerah asal dan daerah hasil.

2. Dengan melakukan langkah-langkah pemodelan pada situasi yang berbeda siswa dapat mengidentifikasi suatu fungsi linier, membuat sketsa tabel, membuat grafik fungsi linier, serta menghitung daerah hasilnya. Dari hasil analisa tersebut pula dengan bimbingan guru siswa dapat membuat rumusan sendiri dan menemukan konsep fungsi linier. Kemudian siswa mampu menyelesaikan permasalahanpermasalahan dalam kehidupan sehari-hari mengenai fungsi linier.

Berdasarkan kesimpulan yang telah dijelaskan, beberapa saran yang dapat direkomendasikan pada penelitian ini adalah sebagai berikut.

1. Bagi siswa, sebaiknya siswa lebih aktif dalam mengikuti proses pembelajaran dan berani dalam mengeluarkan pendapat, ide dan gagasan mereka sehingga proses pembelajaran dapat berjalan dengan lebih maksimal.

2. Bagi guru, disarankan agar guru dapat menerapkan dan mengembangkan lintasan belajar materi fungsi linier dari hasil penelitian ini dalam proses 
pembelajaran. Selain itu terlibat aktif dalam mendesain kembali materi pembelajaran matematika dengan langkah-langkah pemodelan matematika yang disesuaikan dengan kurikulum yang berlaku dan melibatkan konteks atau situasi yang menarik dan disesuaikan pada kondisi siswa sehingga membuat siswa lebih termotivasi dalambelajar.

3. Bagi peneliti lain, hasil penelitian ini dapat dijadikan rujukan dan penelitian-penelitian selanjutnya berkaitan dengan pembelajaran fungsi linier, pemodelan matematika dan desain riset, karena penelitian desain pemodelan matematika ini telah berhasil dilaksanakan dan memberikan kontribusi bagi pembelajaran matematika menjadi bermakna.

\section{DAFTAR PUSTAKA}

Ang, K. C. 2009. Mathematical modeling and real life problem solving. In B. Kaur,B.H. Yeap, \& M., Kapur. (Eds), Mathematical Problem Solving: Association of Mathematics Educators Yearbook 2009. Hal. 159-182. Singapore: World-Scientific.

Bardini, C. dan Stacey, K. 2004. Teachinglinear Functions in Context withGraphics Calculators: StudentResponses and the Impact of theApproach on Their Use ofAlgebraic Symbols InternationalJuornal of Science andMathematics Education, No.2, Hal. 353-376.

Bliss, K. dan Libertini, J. 2016. Guidelines for assessment \& instruction in mathematical modeling education (GAIMME) chapter 1, USA: COPAM, Inc. \& SIAM.
Blum, W. dan Ferri, R. B. 2009. Mathematical modelling: Can it be taught and learnt?. Journal of Mathematical Modelling and Application. Volume 1. No.1. Hal. 45-58.

Bustang, dkk. 2013. Developing a Local Instruction Theory for Learning the Concept of Angle through Visual Field Activities and Spatial Representations International Education Studies Volume 6. Hal.58

Chamberlin, S. A., \& Moon, S. M. 2008. How does the Problem Based Learning Approach Compare to the Model-Eliciting Activity Approach In Mathematics. International Journal for Mathematics Teaching and Learning, Volume 9. No.3. Hal. 78-105.

Gravemeijer, K. 2004.Creating opportunities for students to reinv ent mathematics. Proceedings of the 10th Conference of the International Congress of Mathematics Education.Hal. 1-17.

Gravemeijer, K. 2004. Local instruction theories as means of support for teachers in reform mathematics education. Mathematical thinking and learning, Volume 6. No.2.Hal.105-128.

Gravemeijer, K. P. E., dan Cobb, P. 2006. Design Research From A Learning Design Perspective . In J. V. D Akker, K. P. E Gravemeijer., S. McKennedy, N. Nieven (Eds)., Educational Design Research. Hal. 17-51. London: Routledge. 
Kemendikbud. 2016. Peraturan menteri pendidikan dan kebudayaan nomor 22 tahun 2016 tentang standar proses pendidikan dasar dan menengah. Jakarta: Kemendikbud.

Kilpatrick, J., dan Izsak, A. 2008. A historyof algebra in the schollcurriculum In C.E. Greene \&R.Rubenstein(Eds), Algebra and Algebraic Thingking in School Mathematics.70 th Yearbook ofthe National Council of Teachers of Mathematics. Hal.3-18. Resston, VA:NCTM

National Council of Teachers of Mathematics (NCTM). 2000. Principles and standards for school mathematics. Reston, VA: Author.

Ngatini. 2012. Peningkatan Keaktifan dan Hasil Belajar Matematika MateriFungsi melalui Model Pembelajaran Numbered HeadsTogether bagi Siswa SMP.

Nuraini, N. 2011. Model pembelajaran mata kuliah pemodelan matematika program studi matematika ITB, Prosiding Seminar Nasional Matematika dan Pendidikan Matematika FMIPA UNY, Hal. 150-156, Desember 2011.

Permana, Y. 2007. Mengembangkan kemampuan penalaran dan koneksi matematik siswa SMA melalui pembelajaran berbasis masalah. Educationist, Volume 1. No.2. Hal 116.

Pierce, R. 2005. Linear Functions and a Triple Influence of Teaching on the Development of Student Algebraic Expectation. Proceedings of the
29thConference of the InternetionalGroup for the Psychology of Mathematics Education, Volume 4 Hal. 8188.University of Ballarat.

Plomp, T., dan Nieveen, N. 2007. Educational Design Research: an Introduction. In Plomp, T., \& Nieveen, N. (Editor). An Introduction To Educational Design Research. Hal. 9-35, Enschede: slo.

Pollak, H. 2003. The Interaction between Mathematics and Other School Subjects. In: UNESCO (Ed.). New Trends in Mathematics Teaching IV. Paris. Hal. 232-248.

Purwanto, N. 2002. Pembelajaran Matematika yang Menyenangkan. Jakarta: Departemen Pendidikan Nasional Direktorat Jenderal Pendidikan Tinggi.

Sutomo, Budi. 2016. Sukses Wirausaha. Kriya Pustaka. Jakarta.

Syahrir. 2017. Application of Cooperative Learning Model Index Card Match Type in Improving Student Learning Results on Composition and Composition Functions of Functions Invers in MAN 1 Mataram. Aksioma Jurnal Pendidikan Matematika FKIP Univ. Muhammadiyah Metro. Volume 6. No.3. Hal. 414-420. http://ojs.fkip.ummetro.ac.id/inde x.php/matematika/article/view/11 53/pdf

Widyastuti. 2011. Pengaruh model pembelajaran eliciting activities terhadap kemampuan representasi matematis siswa. http://semnaspendmipa .files.wordpress.com/.../ 
ISSN 2089-8703 (Print) Vol. 7, No. 1 (2018)

ISSN 2442-5419 (Online)

prosiding-seminar-

nasionalpendidikan-mipa-

2011.pdf.

Yee, L.P. \& Hoe, L.N. 2009. Teaching

primary school mathematics.

Singapura: Mc Graw-Hill. 